\title{
Socio-Economic Analysis of Subsistence Farming Practices in South-Western Nigeria
}

\author{
Olawamiwa Reuben Adeniyi ${ }^{1}$ \\ ${ }^{1}$ Department of Agricultural Economics and Extension, Bowen University, Iwo, Osun State, Nigeria \\ Correspondence: Olawamiwa Reuben Adeniyi, Department of Agricultural Economics and Extension, Bowen \\ University, Iwo, Osun State, Nigeria. Tel: 234-803-581-0932. E-mail: adeniyiwamiwa2008@yahoo.com
}

Received: June 15, 2012 Accepted: August 25, 2012 Online Published: November 2, 2012

doi:10.5539/sar.v2n1p104 URL: http://dx.doi.org/10.5539/sar.v2n1p104

\begin{abstract}
Limited knowledge is available regarding how the subsistence-oriented agricultural production in Nigeria is practiced in order to provide policy guides for its future development. This study focused on the cropping patterns, enterprise combination and the nature of costs and returns on subsistence farming practices with a view to determining the major variables affecting the farm's economic performance. Data analyzed were obtained from farm survey covering the two major vegetation zones in south western Nigeria. Frequency tables, correlation matrix and regression were used as analytical tools. Results showed that subsistence farming is not absolutely un-profitable but for the fact that farmers operate at sub-optimal levels. Farmers believed that farming was profitable by their subjective evaluation and because it satisfies their subsistence needs. Organized and guided programmes of increasing farm size; reducing labour cost and improving farming techniques could serve as saviours to enhance income on subsistence farms.
\end{abstract}

Keywords: socio-economic, subsistence-oriented, farming practices, organized and guided programmes, enhanced income

\section{Introduction}

Opinions about peasantry cum subsistence production are diverse and at times, judgments on the measures of degrees of peasantry existing in a particular economy are based on subjective scoring. In fact, many authors use the words subsistence and peasantry inter-changeably. As typical of low-income countries of the world, subsistence production in Nigeria and peasantry in countries like Asia, Japan and Latin America may be ranked equal especially with regard to their set up and management of resources. However, the relative sense in which each of them is used is particularly a matter of degree. With Nigerian subsistence, farm sizes are small, (ranges between 0.81 and 2.02 hectares in this study) and the farm family supplies the bulk of labour force, management and capital and consumes a lot of the farm proceeds leaving room for small marketable surplus. The same farmers who produce food crops mainly for consumption are also engaged in production of other crops for export sales. Thus, there is an intermixing of farm business operations with family considerations (see also Hill, 1966; Hunter, 1969; Adeniyi, 1983).

Although the Asian and Japanese peasantry involves small-holder farmers operating on about 2 hectares of land, the system is capital intensive, mechanized and generates large marketable surplus through improved management practices (Uwah, 1975).

Much of the research work carried out on subsistence farms in Nigeria are largely general with little attention being given specifically to enterprise combination and profitability of all the farm and farm-related occupations engaged in by the farmers and their likely overall effects on the economics of farm production. The main objectives of the current study therefore are:

(a) to study the economics of subsistence farms in Oyo and Osun States in the south west of Nigeria with a view to determining their efficiency;

(b) to examine the farmers' notion of profitability in relation to subsistence farming;

(c) to suggest possibilities and make recommendations for improving the economic performance and efficiency of subsistence farms in the study area. 
The study covers both the deciduous and savannah vegetation zones of south western Nigeria hence results obtained can be applied to areas in and outside the country having similar ecology, resource endowment and technology.

\subsection{The Data}

This study was carried out in Oyo and Osun states of southwestern Nigeria. The study area was zoned on NorthSouth basis using the type of vegetation and crops raised. While the northern farmers are typical food crop farmers having mixed savannah vegetation structure, the southern part is typically grown to tree crops with deciduous forests.

The field survey was carried out through structured questionnaire schedules administered by personal interviews. This was supplemented with information collected from agricultural assistants, agricultural extension agents and agricultural staff on the Cocoa Development Units (C.D.U.) and ministries of agriculture and economic planning in each of the study areas. Farmers were interviewed about their farm and farm-related activities as well as their subsidiary income-earning occupations. Variables covered included the farmers' demographic characteristics, production practices, nature of expenses and receipts, goals of subsistence and factors considered affecting their performance on subsistence farms. The first set of information was collected in 1982/83 cropping season and this was reviewed between July 1986 and January 1987.The most recent survey being reported in this study was carried out between June 2009 and February 2010.

A random sample of 200 small scale farmers was selected for interview in a total of 24 villages in each of the first two surveys while for the last survey, 218 farmers were sampled from 20 villages. (See Adeniyi $(1983,1988)$ for details of the previous surveys). However, responses from only 180 farmers who cooperated fully in the 2009/2010 survey were analyzed for this study.

\subsubsection{Methods of Analysis}

Owing to the fact that the information collected through the field survey was mostly qualitative in nature, the method of analysis used was mainly frequency tabulation. However, descriptive and quantitative methods were used whenever data collected make such analyses possible. Profitability as a quantitative variable was examined by using Pearson's correlation matrix and multiple regression analysis.

Usually, the net income derivable on farms is a function of socio-economic consideration rather than statistical relationship. However, in order to subject the socio-economic relationship to quantitative estimation, we need to specify a model which allows both economic and statistical considerations to bear on the model. This is necessary since the socio-economic factors influencing the production decisions to be explained must be considered. These relationships are however not all exact and therefore have to be estimated statistically before subjecting the parameters to empirical testing. To this end, the method of "Ordinary Least Squares" (OLS) was used to estimate the functional relationship between the dependent variables and the set of explanatory variables. The model is indicated in equation 1. The variables are as defined in Appendix 1.

$$
\mathrm{NI}=f(\mathrm{FS}, \mathrm{AG}, \mathrm{FT}, \mathrm{CE}, \mathrm{TL}, \mathrm{FD}, \mathrm{HL}, \mathrm{CL}, \mathrm{Ut})
$$

equation (1)

$\mathrm{Ut}=$ stochastic error term

Both the power and linear forms were initially specified and after comparing their results, the linear forms appeared more appropriate. The algebraic form of the linear equations is shown in equation 2 . The variables are as previously defined.

$$
\mathrm{NI}=\mathrm{a}_{0}+\mathrm{a}_{1} \mathrm{FS}+\mathrm{a}_{2} \mathrm{AG}+\mathrm{a}_{3} \mathrm{FT}+\mathrm{a}_{4} \mathrm{CE}+\mathrm{a}_{5} \mathrm{TL}+\mathrm{a}_{6} \mathrm{FD}+\mathrm{a}_{7} \mathrm{HL}+\mathrm{a}_{8} \mathrm{CL}+\mathrm{Ut}
$$

The evaluation of the model was based on the following criteria:

(a) The correlation matrix to test for multicollinearity among explanatory variables.

(b) $\bar{R}^{2}$ (adjusted $\mathrm{R}^{2}$ ) which was used to know the extent to which the variability in net income derivable on farms was explained by the variations in the explanatory variables with adjustments made for differences in the degrees of freedom.

(c) The "F" values which were used to test the significance of the overall model.

(d) The size of standard errors of estimated coefficients together with the " $t$ " statistic which was used to test for the significance of the individual estimated coefficients.

The underlying assumptions of the model include normality; zero means, non-auto regression and homo skedasticity (see Kmenta (1971) for details). 
After the first run of the computer, it was shown that farm size alone singly explained the highest percentage of about 75 percent of the variations in net farm income; hence it was thought necessary to combine other variables with size in a step-wise regression against net farm income as the dependent variable. The correlation matrix obtained indicated some likely problems of multicolinearity amongst some of the independent variables. This exercise however helped in eliminating collinear and weak explanatory variables in order to choose the lead equations used in this study.

\section{Empirical Results and Discussion}

\subsection{Some Socio-economic Characteristics}

\subsubsection{Size of Farm}

The result of analysis on size of farm as shown in Table 1 reveals that there is a positive relationship between farm size and the net revenue derivable by farmers. This is however expected. Unfortunately, quite a majority (about 63\%) of farmers cultivates farm sizes that are most often less than 4 hectares (mean) for all crops raised (including tree crops).

Table 1. Averages of total cost, total revenue and net revenue by size group (\#’00)

\begin{tabular}{ccccccccc}
\hline & & \multicolumn{3}{c}{ Averages of } & \multicolumn{3}{c}{ Averages of per hectare } \\
\hline $\begin{array}{c}\text { Size of farm } \\
\text { (hectares) }\end{array}$ & $\begin{array}{c}\text { No. of } \\
\text { farmers }\end{array}$ & $\begin{array}{c}\text { Total } \\
\text { Hectare }\end{array}$ & $\begin{array}{c}\text { Total } \\
\text { Revenue }\end{array}$ & $\begin{array}{c}\text { Total } \\
\text { Cost }\end{array}$ & $\begin{array}{c}\text { Net } \\
\text { Revenue }\end{array}$ & $\begin{array}{c}\text { Total } \\
\text { Revenue }\end{array}$ & $\begin{array}{c}\text { Total } \\
\text { Cost }\end{array}$ & $\begin{array}{c}\text { Net } \\
\text { Revenue }\end{array}$ \\
$0.40-2.02$ & 54 & 76.52 & 1153.55 & 740.16 & 413.39 & 15.08 & 9.67 & 5.4 \\
$2.03-4.05$ & 60 & 189.47 & 2019.63 & 1206.51 & 813.12 & 10.66 & 6.37 & 4.29 \\
$4.06-6.06$ & 30 & 154.25 & 3125.74 & 1327.52 & 1798.22 & 20.26 & 8.61 & 11.66 \\
$6.07-8.09$ & 24 & 180.97 & 5850.14 & 2948.14 & 2901.34 & 32.33 & 16.29 & 16.03 \\
$8.10-10.12$ & 6 & 60.73 & 5178.5 & 2641.27 & 237.23 & 85.27 & 43.49 & 41.78 \\
$10.13-12.15$ & 3 & 34 & 5826.69 & 2453.04 & 2373.65 & 171.31 & 101.54 & 69.81 \\
$12.16-14.11$ & 3 & 40 & 6773.84 & 2593 & 4185.84 & 169.13 & 64.7 & 104.44 \\
Total & 180 & 736.03 & 2702.98 & 1427.45 & 1275.52 & 24.28 & 1285 & 11.42 \\
\hline
\end{tabular}

\# means Naira (Nigerian Currency). $\$ 1$ is equivalent to 150 as at the time of this study.

Source: Computed from survey data.

\subsubsection{Level of Technology Adopted by Farmers}

The various items of modern farming techniques available to the farmers in the study area included the use of tractors, insecticides, fungicides, herbicides, fertilizer, improved seeds and seedlings as well as the adoption of farming methods recommended by the extension agents. Each of these items was assigned a weight based on its considered qualitative contribution to enhancing farm returns. In this case, full mechanization of farms was weighted 1 while the use of tractors attracted a weight of 0.25 . All other items had 0.125 each (see the Appendix) The weighted fractions of all items used by each farmer on his farm are summed up to group the farmers.

The net effect of the use of these varying items of modern farming techniques and equipment is summarized in Table 2. The observed increase in the average total cost, total revenue and net revenue with an improvement in the levels of modern technology adopted by farmers in the study area is not too different from reality. Modern technology is capital intensive although highly rewarding economically. As more modern inputs are introduced on the farm, additional costs on these purchased inputs are inevitable. This however in turn will make the farm operators more comfortable in terms of his additional net earnings which increase more than proportionately than the additional costs. 
Table 2. Averages of total cost, total revenue and net revenue by the level of technology adopted on farms + (\#’00)

\begin{tabular}{ccccccccc}
\hline $\begin{array}{c}\text { Level of } \\
\text { Technology } \\
\text { adopted(hectares) }\end{array}$ & $\begin{array}{c}\text { Number } \\
\text { of } \\
\text { farmers }\end{array}$ & $\begin{array}{c}\text { Total } \\
\text { Hectare }\end{array}$ & $\begin{array}{c}\text { Total } \\
\text { Revenue }\end{array}$ & $\begin{array}{c}\text { Total } \\
\text { Cost }\end{array}$ & $\begin{array}{c}\text { Net } \\
\text { Revenue }\end{array}$ & $\begin{array}{c}\text { Total } \\
\text { Revenue }\end{array}$ & $\begin{array}{c}\text { Total } \\
\text { Cost }\end{array}$ & $\begin{array}{c}\text { Net } \\
\text { Revenue }\end{array}$ \\
\hline $\begin{array}{c}\text { Nil (0) } \\
\text { Below Average } \\
(0.15-0.375)\end{array}$ & 42 & 86.23 & 1458.43 & 805.94 & 652.49 & 16.91 & 9.35 & 7.56 \\
$\begin{array}{c}\text { Average level } \\
(0.5)\end{array}$ & 54 & 167.61 & 2004.17 & 1163.87 & 840.3 & 11.9 & 6.94 & 5.01 \\
$\begin{array}{c}\text { Above Average } \\
(0.625-0.875)\end{array}$ & 36 & 296.79 & 5379.96 & 2723.43 & 18.01 & 8.89 & 9.12 & \\
$\quad \begin{array}{c}\text { Full } \\
\text { Mechanization(1) }\end{array}$ & - & - & - & - & - & - & - & - \\
$\quad$ Total & 180 & 736.03 & 2702.97 & 1427.47 & 1275.5 & 14.84 & 7.98 & 6.86 \\
\hline
\end{tabular}

+ Figures in parentheses represent averages of the sum of weighted fractions of all items of modern farming techniques used by the farmers.

\# means Naira (Nigerian Currency). $\$ 1$ is equivalent to $\$ 150$ as at the time of this study.

Source: Computed from survey data.

\subsection{Correlation Matrix}

Table 3 shows the result of the correlation analysis. It could be observed that age of farms is negatively related to farm income while the number of enterprises combined on farms has positive relationship. The former evidence confirms the adverse effect of ageing farming population on farm income while the latter indicates the positive effect of enterprise diversification on incomes from subsistence farming. The size of farm dependants' variable shows minimal or unimportant effect on the direction of farm profitability.

Other variables specified in the model show very weak relations with the net farm income, none-the-less, they at least indicate their individual effects on the direction of overall farm business. The negative response to the use of family labour on farms considered alongside the positive response shown by the use of hired labour are explained in terms of low relative productivity of family vis-à-vis hired labour prevalent amongst subsistence farmers in underdeveloped countries (see also, Hunter, 1969; Ogunfowora et al.,1975; Durrant 1980; Adeniyi, 1983).

Table 3. Correlation matrix: net income of farms and socio-economic characteristics of farmers

\begin{tabular}{llllllllll}
\hline Variables* & NI & FS & AG & FT & CE & TL & FD & HL & CL \\
\hline NI & 1 & & & & & & & & \\
FS & 0.599 & 1 & & & & & & & \\
AG & -0.235 & -0.251 & 1 & & & & & & \\
FT & -0.381 & -0.581 & 0.199 & 1 & & & & & \\
CE & 0.275 & 0.53 & -0.094 & -0.391 & 1 & & & & \\
TL & 0.445 & 0.657 & -0.093 & -0.446 & 0.428 & 1 & & & \\
FD & 0.045 & 0.041 & 0.22 & -0.055 & -0.187 & -0.089 & 1 & & \\
HL & 0.39 & 0.689 & -0.307 & -0.856 & 0.597 & 0.539 & -0.068 & 1 & \\
CL & 0.389 & 0.689 & -0.308 & -0.854 & 0.598 & 0.54 & -0.068 & 0.999 & 1
\end{tabular}

*See appendix for the definition and explanation of variables (characteristics) included in the correlation matrix.

Source: Computed from survey data. 
An examination of the correlation matrix indicates to us the degree of multicollinearity among the explanatory variables. Opinions vary on the exact degree of multicollinearity that poses a very serious problem for a study involving time series data (Orcutt \& Cochran, 1949; Johnston, 1963). However, for the purpose of the present study, it is assumed that any pair of correlation coefficient that is more than 0.70 would pose serious multi-co linearity problems. Thus, as shown in the table, the third and seventh independent variables are multicollinear and this was noted and considered in specifying equations for the regression analysis.

The table also showed in order of importance that farm size, level of technology adopted by farmers, degree of hired labour used on farms, the number of enterprises combined on the farms and the total number of members of the extended farm family are all positively correlated with net income. Age of farms and the amount of family labour used on farms however, have negative correlations. There are low correlations between the net income and age of farms as well as the number of enterprises combined by farmers.

\subsection{Multiple Regression Analysis}

The empirical results of the regression analyses are presented in Tables 4 and 5. As shown in Table 4, all the variables considered except the total number of farm family members and the dependent relatives are found to be statistically significant at $1 \%$ level.

Table 4. Regression results

\begin{tabular}{ccccccc}
\hline $\begin{array}{c}\text { Dependent } \\
\text { Variable (NI) }\end{array}$ & $\begin{array}{c}\text { Constant } \\
\left(\mathrm{a}_{\mathrm{o}}\right)\end{array}$ & $\begin{array}{c}\text { Coefficient of } \\
\mathrm{Xi}\left(\mathrm{a}_{\mathrm{i}}\right)\end{array}$ & $\begin{array}{c}\text { Standard } \\
\text { error(S.E.) of Xi }\end{array}$ & $\begin{array}{c}\text { Value of t- } \\
\text { calculated. }\end{array}$ & $\begin{array}{c}\text { Value of } \\
\mathrm{R}^{2}\end{array}$ & $\begin{array}{c}\text { F- } \\
\text { Value }\end{array}$ \\
\hline $\mathrm{NI}$ & 90.54 & $+111.79 \mathrm{FS}$ & 11.21 & 9.97 & 0.75 & 99.48 \\
$\mathrm{NI}$ & 2063.03 & $-25.86 \mathrm{AG}$ & 8.01 & 3.23 & 0.15 & 10.41 \\
$\mathrm{NI}$ & 2399.31 & $-82.78 \mathrm{FT}$ & 15.05 & 5.5 & 0.54 & 30.28 \\
$\mathrm{NI}$ & 415.17 & $+108.47 \mathrm{CE}$ & 28.38 & 3.82 & 0.47 & 14.6 \\
$\mathrm{NI}$ & 418.95 & $+545.92 \mathrm{TL}$ & 82.45 & 6.62 & 0.59 & 43.84 \\
$\mathrm{NI}$ & 1092.18 & $+10.33 \mathrm{FD}$ & 17.26 & 0.6 & 0 & 0.36 \\
$\mathrm{NI}$ & 776.91 & $+0.53 \mathrm{HL}$ & 0.9 & 5.89 & 0.54 & 31.8 \\
$\mathrm{NI}$ & 767.23 & $+0.54 \mathrm{CL}$ & 0.09 & 5.64 & 0.55 & 3180 \\
\hline
\end{tabular}

Note: The value of $\mathrm{t}-$ tabulated at: $(1 \%, 180)=2.576 ;(5 \%, 180)=1.96$.

$\mathrm{NI}=\mathrm{a}_{\mathrm{o}}+\mathrm{a}_{\mathrm{i}} \mathrm{X}_{\mathrm{i}}$

$a_{\mathrm{o}}=$ constant

$\mathrm{a}_{\mathrm{i}}=$ slope

$\mathrm{X}_{\mathrm{i}}=$ explanatory variable

Source: Computed from survey data.

The values of $\mathrm{R}^{2}$ show that while the size of farm alone explains 75 percent of the variations in net income, the level of technology adopted by farmers, the proportion of family to total farm labour and the level of hired labour used on farms explain 59,54 and 54 percent respectively. The age of farms explains only 15 percent of the variations in net income while the size of farm family does not explain any variations at all, among the sample of farmers.'

In view of the strong relationship (multicollinearity) noticed between variables 3 and 7 (see Table 3), the two variables are merged into one and re-defined as the total cost of labour to reflect the addition. A separate computer run, using this new variable shows that it singly explains up to $55 \%$ of the variations in farmers' net income and is also statistically significant at $1 \%$ level.

Table 5 gives the summary of the final step-wise regression analysis results estimating the effect of the more highly significant variables on the net income of farmers. 
Table 5. Regression results' equations

\begin{tabular}{|c|c|}
\hline No. & Equations \\
\hline \multirow[t]{3}{*}{ (i) } & $\mathrm{NI}=1309.02-49.58 \mathrm{FT}^{* * *}+420.74 \mathrm{TL}^{* * *}$ \\
\hline & $(15.91) \quad(89.97)$ \\
\hline & $\mathrm{R}^{2}=0.63 \quad \mathrm{~F}=27.85$ \\
\hline \multirow[t]{3}{*}{ (ii) } & $\mathrm{NI}=384.19+405.90 \mathrm{TL}^{* * *}+0.92 \mathrm{HL}^{* * *}$ \\
\hline & $(96.25) \quad(0.11)$ \\
\hline & $\mathrm{R}^{2}=0.62 \quad \mathrm{~F}=26.32$ \\
\hline \multirow[t]{3}{*}{ (iii) } & $\mathrm{NI}=378.87+406.18 \mathrm{TL}^{* * *}+0.29 \mathrm{CL} * * *$ \\
\hline & $(96.26) \quad(0.11)$ \\
\hline & $\mathrm{R}^{2}=0.62 \quad \mathrm{~F}=26.31$ \\
\hline \multirow[t]{3}{*}{ (iv) } & $\mathrm{NI}=300.129+106.36 \mathrm{FS} * * *-10.86 \mathrm{FT}$ \\
\hline & $(13.80) \quad(16.05)$ \\
\hline & $\mathrm{R}^{2}=0.75 \quad \mathrm{~F}=49.82$ \\
\hline \multirow[t]{3}{*}{ (v) } & $\mathrm{NI}=217.27+96.79 \mathrm{FS} * * *-9.05 \mathrm{FT}+104.84 \mathrm{TL}$ \\
\hline & $\begin{array}{lll}(16.46) & (16.13) & (98.43)\end{array}$ \\
\hline & $\mathrm{R}^{2}=0.75 \quad \mathrm{~F}=33.61$ \\
\hline \multirow[t]{3}{*}{ (vi) } & $\mathrm{NI}=839.94+107.52 \mathrm{FS}-43.83 \mathrm{FT}+126.75 \mathrm{TL}-0.32 \mathrm{HL}$ \\
\hline & $\begin{array}{llll}(17.40) & (25.06) & (98.56) & (0.18)\end{array}$ \\
\hline & $\mathrm{R}^{2}=0.76 \quad \mathrm{~F}=26.34$ \\
\hline \multirow[t]{3}{*}{ (vii) } & $\mathrm{NI}=26.30+107.41 \mathrm{FS}+122.05 \mathrm{TL}-0.08 \mathrm{CL}$ \\
\hline & $(17.50) \quad(99.10) \quad(0.11)$ \\
\hline & $\mathrm{R}^{2}=0.75 \quad \mathrm{~F}=33.72$ \\
\hline
\end{tabular}

Note: The figure in bracket below each coefficient represents the standard error of the estimate.

*** Coefficient is statistically significant at $1 \%$ level.

Source: Computed from survey data.

It was shown in Table 4 that the farm size variable alone explains 75 percent of the variations in the farmers' net income and the coefficient is statistically significant at $1 \%$ level. As the proportion of family to total farm labour is added to the size of farm as a separate variable, the value of $\mathrm{R}^{2}$ remains unchanged at 0.75 , still, only the size of farm variable is statistically significant at $1 \%$ level (see equation iv of Table 5). The other variable added (i.e. the proportion of family to total farm labour) is not significant even at $40 \%$ level.

Equations(i) - (iii) of Table 5 reveal that with the exclusion of size of farm variable, other variables considered in the model are statistically significant at $1 \%$ level, and jointly explain about 62 percent of the variations in the net farm income among the sample of farmers. Their F-statistic is also statistically significant at $1 \%$ level. However, only 76 percent of the variations in net income could be explained by the joint effects of size with the other three variables that were initially statistically significant at $1 \%$ level (see equations (vi) and (vii) of table 5). This is just an improvement of $1 \%$ above that of size of farm variable considered singly.

From the foregoing discussions, it could be concluded that three major important socio-economic characteristics of farmers which can enhance net farm revenue of subsistence farmers are the size of individual farm holdings, the level of technology adopted on farms and the labour cost reduction programmes.

Statistical analysis shows however that the most important income-enhancing factor is the increase in size of farm holdings. This is followed in order of importance by the labour cost reduction programmes and the improvement in technological levels on the farms. 


\subsection{The Notion of Profitability as Perceived by Farmers in the Study Area}

It is clear from the analysis that farmers in the study area are at least making some reasonable levels of net income on their farm holdings though there are still ample potentials for them to increase their profit margin at the level of available resources. This is evident from the fact that many farmers cultivate farm sizes smaller than the mean and also employ farming techniques that are not the most economically ideal for the study area.

The desire to make profit is ultimately much emphasized in any growing concern and, subsistence farming as a part of the overall economic activities in Nigeria is not an exception. This fact is amply demonstrated by the farmers' responses as to profitability of their operations. Majority of the farmers $(57 \%)$ considered farming profitable because it enables them to have sufficient food for the family and at the same time have surplus for sale so as to provide them enough funds to buy some necessities of life and meet educational expenses of their children.

Thirty percent $(30 \%)$ considered farming profitable because the value of harvest is at least larger than that of the seeds sown while the rest 13 percent, majority of whom are part time farmers felt that farming is not absolutely unprofitable but when relative comparisons are made with other contemporary businesses engaged in by them, it is not as profitable.

Various reasons were given by farmers about their levels of satisfaction with farming jobs. About 32 percent felt satisfied because farming was and is a major source of food supply to the family, 28.33 percent were satisfied because it enabled them to meet farm family's cash and other incidental expenses, 13.33 percent felt satisfied since as part-time farmers, their harvests from cultivated arable crops helped to reduce their expenses on food for the family. The remaining 26 percent were however, dissatisfied with their condition as farmers only because of the drudgery associated with farming and also the belief of the general public that farming is a 'poor' man's job.

On their reactions to continuity of work in the face of possible adverse conditions on their farms, about 96.67 percent pledged to continue production even with condition of total crop failure and 97 percent said they would still prefer to retain ownership of land either for farming $(62 \%)$ or fallowing $(35 \%)$. These, according to them would at least enable them to retain title to such lands.

The fact that a majority of the farmers considered farming profitable and satisfying because it provides food and other need (sustenance) agrees with the subsistence orientation of most of the farmers. The willingness of an overwhelming majority (almost 97\%) to continue production and at least retain title to their land holdings even under conditions of total crop failure demonstrates that subsistence farmers owe allegiance to the family-owned lands and would try as much as possible to protect the family interests on such lands. Also, the fact that majority of them take to farming after their parents and had no other vocational training from birth, contribute to their continued stay on the farms.

\section{Conclusion}

The general performance of subsistence farmers in the study area is dependent not only on economic motivations but also on socio-cultural considerations. However, in order to make the currently active farmers more economically satisfied and to encourage both old and new hands coming into farming, there is need for radical government policies in the areas of provision of functional education to farmers to improve their decision making processes, supply of farmers with modern productivity and labour-enhancing inputs like fertilizers, herbicides, etc. These should be complemented with adaptive mechanized technology to suit the prevailing system of agricultural practice among Nigerian subsistence farmers. Finally, efforts should be made to provide the additional requisite technical guidance.

\section{References}

Adeniyi, O. R. (1983). The Economics of subsistence farms in Nigeria; A Case Study of Oyo-Oshun Divisions of Oyo State, M. Sc. Thesis, Department of Agricultural Economics, University of Ife, Nigeria.

Adeniyi, O. R. (1988). Farm Management Decisions of Small-holder Farmers in Isoya Group of Villages, Ph.D Thesis, Department of Agricultural Economics, Obafemi Awolowo University Ile-Ife, Nigeria.

Durrant, N. D. (1980). An Analysis of Capital Formation among a sample of peasant farmers in Bendel State of Nigeria. Unpublished M. Phil. Thesis, Department of Agricultural Economics, University of Ife, p. 13.

Hill, P. (1966). A plea for indigenous economics, the West African Example. Economic Development and Cultural Change, 15(1), 12. http://dx.doi.org/10.1086/450194

Hunter, G. (1969). Modernizing Peasant societies. A Comparative Study in Asia And Africa, Parts 1 and 2 New York, Oxford University Press, p. 324. 
Johnston, J. (1963). Econometric Methods, Mc-Graw-Hill Book Company, Inc. New York, (2nd ed.). p. 179.

Kmenta, J. (1971). Elements of Econometrics, Macmillan Publishing Coy. Inc.

Ogunfowora, O., Essang, S. M., \& Olayide, S. O. (1975). Resource Productivity in Traditional Agriculture: A case study of four Agricultural Divisions in Kwara State Nigeria Rural Development Paper No. 16; Department of Agricultural Economics, University of Ibadan, Nigeria.

Orcutt, G. H., \& Cochrane, D. (1949). Applications of Least Squares Regression to Relationships containing auto correlated Error terms. Journal of American Statistical Association, 44(245), 32-61. http://dx.doi.org/10.1080/01621459.1949.10483312

Uwah, E. D. (1975). Subsistence Farming and Rural Development. A case study of some selected villages of Oyo State of Nigeria. Unpublished M.Sc. thesis, Department of Agricultural Economics University of Ibadan.

\section{Appendices}

Appendix 1

Definition of Variables Used

$\mathrm{NI}=$ Net Income per farmer expressed in Naira (\#)

$\mathrm{FS}=$ Size of farm measured by the hectare of farm cultivated to various enterprises.

$\mathrm{AG}=\mathrm{Age}$ of farms evaluated as the number of years during which farm has been continuously cultivated.

FT= Proportion of family labour used on the farm expressed in man days.

$\mathrm{CE}=$ Number of enterprises combined on the farm by the farmers.

TL Level of technology adopted on the farm measured qualitatively.

The items of modern technology available to farmers in the study area include use of tractors, use of chemicals like insecticides, fungicides, herbicides and fertilizer, use of improved seeds and seedlings as well as the adoption of farming methods recommended by the extension agents. Subjective weights are assigned to each of these different items of modern technology usable on farms based on their assumed contribution to farms income. Full mechanization attracted a weight of 1 ; implying privileged farms that had access to and used all the items of modern farming technologies available. Use of tractors to enhance labour supply and productivity is weighted 0.25 and each of all the other items of modern technology used on farms attracted a weight of 0.125 . These assumptions are arrived at through information obtained from farm surveys of the study area and the results of various work-studies and on-farm practices in similar ecological areas.

$\mathrm{FD}=$ Total number of members of the farm family plus the dependent relatives.

$\mathrm{HL}=\mathrm{Cost}$ of hired labour used on the farm as a proportion of the total cost of production on the farms.

$\mathrm{CL}=$ Total cost of all kinds of labour (Hired and family) employed on the farm. 